\title{
Islamism, secularization, secularity: the Muslim Brotherhood in Egypt as a phenomenon of a secular age
}

\section{Katerina Dalacoura}

Katerina Dalacoura, London School of Economics, Houghton Street, London WC2A 2AE, United Kingdom. E-mail: K.Dalacoura@lse.ac.uk

\begin{abstract}
The paper outlines parallels between the processes of secularization and secularity in the West, as interpreted by José Casanova and Charles Taylor, and Islamism as a modern social and political phenomenon. It focuses on the Egyptian Muslim Brotherhood's history and ideas and specifically on a number of public documents detailing its social and political vision. I argue that if we define 'secularization' not only as the weakening of religious belief, but as the institutional differentiation of modern state structures and the marginalization of religion; and 'secularity' as the process whereby faith becomes one option among others and religion becomes an identifiable set of beliefs seen as guidelines for reform, the Brotherhood, similarly to other Islamist entities, is a phenomenon of a 'secular age'.
\end{abstract}

Keywords: secularity; secularization; Islamism; Muslim Brotherhood; modernity.

\section{Introduction}

It may appear counter-intuitive to describe the Muslim Brotherhood in Egypt committed since its inception in 1928 to the Islamization of Egypt and Muslim society in general - as being a secular entity in any shape or form. However, it is my contention in this paper that 'Islamist' can only be juxtaposed to 'secular' in such stark and simple fashion if the latter is defined solely as the decline of religious belief; and that, if we take on board the more complex meanings of the term - 'secularization' as the process of institutional and functional differentiation of modern state structures and the resultant marginalization of religion and 'secularity' as the process by which faith becomes one option among others - the Brotherhood must be seen, if not as a secular movement, at the very least as a phenomenon of a secular age. 
Gregory Starrett argues that 'the secular's unfixedness is one of its essential features' and that its 'usefulness as an analytical concept is deeply suspect' (Starrett, 2010, p. 628). Philip Gorski and Ateş Altınordu maintain that we must 'firmly renounce any pretenses to fixing a correct meaning [of the secularization concept] once and for all' (2008, p. 75). These approaches, and the concept of 'multiple secularities' analogous in some ways to 'multiple modernities' - which addresses the manner in which secularity is variously negotiated in specific historical and social settings (Burchardt et al., 2015), provide the backdrop for my argument in this paper. However, even though my starting point is that secularity and secularization (and secularism, though this is not my subject ${ }^{1}$ ) follow diverse paths across history and around the world, my argument ultimately highlights similarity rather than difference across societies and world regions within the modern condition. I follow Casanova's call to 'historicize and contextualize our categories and adopt a more global perspective' (Casanova, 2003, p. 17) (though I disagree with him on the issue of Islam, as I will clarify). But I also take on board his view that, even if the traditional model of secularization no longer offers a plausible account of developments outside Europe, for the United States and the rest of the world (2003, p. 17), it is still useful as 'an analytical framework for a comparative research agenda which aims to examine the historical transformation of all world religions under conditions of modern structural differentiation, as long as the outcome of this transformation is not predetermined by the theory' (2003, p. 23).

The paper demonstrates how processes and structures of secularity and secularization have shaped the worldview and ideology of a seminal Islamist movement, the Muslim Brotherhood in Egypt. It sets the Brotherhood alongside the European/Christian/Western experience - not using it, however, as the theoretical framework or 'ideal type' against which the Brotherhood case is to be measured - and 
concludes that they are not dissimilar, and that the idea of multiple secularities and secularizations should not be pushed so far as to obscure elements of commonality across modern societies. The paper draws on two major thinkers on secularity and secularization in the European/Christian/Western world, José Casanova and Charles Taylor. They are not the only historians or sociologists of secularity and secularization in the West, of course, but they dominate the field - Taylor in particular has been described as 'one of the leading thinkers of our time' (Warner et al., 2010, p. 1). They are also relevant to my argument in that they have both also touched on Islam, mostly to highlight its points of contrast with the West and Christianity. ${ }^{2}$ I maintain that these points of contrast may not be as sharp as Casanova and Taylor have suggested.

\section{Secularization and secularity in the West through the work of José Casanova and}

\section{Charles Taylor}

José Casanova argues that secularization theory consists of three hypotheses differentiation, privatization, and decline - each of which must be treated as separate, and only one of which, differentiation, is plausible (Casanova, 1994, pp. 20, 211; see also Casanova, 2011). Casanova's major work, Public religions in the modern world, published in 1994, deals with case studies drawn from the Christian world (1994, pp. 5-6). It argues that it had become clear by the 1980s that differentiation and the loss of societal functions of religion do not necessarily entail its privatization, let alone its decline. The main fallacy of secularization theory, according to Casanova, was 'the confusion of historical processes of secularization proper with the alleged and anticipated consequences which those processes were supposed to have upon religion' (Casanova, 1994, p. 19). 
The aspect of Casanova's argument most relevant to this paper is his assertion that, whatever the dispute about its consequences, the 'core of the theory of secularization, the thesis of the differentiation and emancipation of the secular spheres from religious institutions and norms, remains valid' (1994, p. 6); and that secular differentiation 'remains a structural trend that serves to define the very structure of modernity' (Casanova, 1994, p. 39). The theory of secularization is a sub-theory of general theories of differentiation, either of the evolutionary or universal kind proposed by Émile Durkheim or the historically specific or Western modernization theory of Max Weber (Casanova, 1994, pp. 17-18). Differentiation entails that 'the state and the economy, as well as other major cultural and institutional spheres of society - science, education, law, art - develops its own institutional autonomy, as well as its intrinsic functional dynamics. Religion itself is constrained not only to accept the modern principle of structural differentiation of the secular spheres but also to follow the same dynamic and to develop an autonomous differentiated sphere of its own' (Casanova, 1994, p. 212).

Charles Taylor expounds on the meaning of 'the secular' in the history of the West in his book $A$ secular age, a major work which, since its publication in 2007 , has molded debates on the subject both in public philosophy and the social sciences. Secularity, as experienced in the West, consists of three aspects. 'Secularity 1' refers to 'common institutions and practices - most obviously, but not only, the state' (Taylor, 2007a, p. 1). The modern Western state is free from the connection with faith or God, churches are separate from political structures and religion or its absence is largely a private matter. Public spaces - which include science, the market, politics, the arts have been 'emptied of God' and 'the considerations we act on are internal to the “rationality" of each sphere'. This emptying of religion from autonomous social spheres 
is compatible, however, with the majority of people still believing in God (Taylor, 2007a, p. 2). The second meaning of secularity according to Taylor, 'secularity 2', is 'the falling off of religious belief and practice, in people turning away from God, and no longer going to Church' (Taylor, 2007a, p. 2). This is what people most think about when they define our times as secular but must be distinguished from 'secularity 3', which focuses on conditions of belief. Taylor's book focuses on secularity in that third sense. It traces the evolution of Western societies from a situation, in 1500 , where it was virtually impossible not to believe in God (where belief was the 'default option') (Taylor, 2007a, p. 12) to one, in 2000, where 'faith, even for the staunchest believer, is one human possibility among others' (Taylor, 2007a, p. 3) and many of us find not believing in God easy and even inescapable (Taylor, 2007a, p. 25). Now unbelief has become the 'default' position (Taylor, 2007a, p. 3). ${ }^{3}$

Secularity 3 , which pertains to conditions of belief, is characterized by a number of inter-related developments. Taylor argues that there emerged, in 'Latin Christendom' following the 'Dark Ages', what he calls the 'buffered self' (Taylor, 2007a, pp. 37-42) which entailed the creation of a boundary between inside (thought) and outside (nature, the physical). It comes about through 'the replacement of a cosmos of spirits and forces by a mechanistic universe' and gives us 'a sense of power, of capacity, in being able to order our world and ourselves' (Taylor, 2007a, p. 300). This development gave 'unprecedented primacy to the individual' and, as a result, society gradually came to be conceived as made up of individuals (Taylor, 2007a, p. 146). In earlier societies there had been an inability to imagine the self outside a particular context, whereas now the abstract question of emigrating or changing religion became possible (Taylor, 2007a, p. 149). By the second half of the twentieth century there arose in Western societies 'a 
generalized culture of "authenticity" or expressive individualism' (Taylor, 2007a, p. 299).

Taylor writes, that 'It has often been noted how secularization went along with an intensification of religious faith'. During the Reformation and Counter-Reformation in Europe, in the seventeenth and eighteenth centuries, religion became a matter of intense personal decision (Taylor, 2007a, p. 143). There was a gradual sorting out in experience "by which it became possible to relate to certain realities as purely "natural", and disintricate them from the transcendent; whereby it eventually became possible to see the immediate surroundings of our lives as existing on this "natural" plane...'. This sorting out was compatible with belief in God and was even 'accompanied by a more conscious and zealous dedication to God' (Taylor, 2007a, p. 143).

The primacy of the individual and the intensification of faith were inextricably linked with the urge to reform which took, in late mediaeval - early modern Europe, the form of 'a drive to make over the whole society to higher standards' (Taylor, 2007a, pp. 62-63). Reforms rested on the idea that each individual will face judgment upon death and encouraged the spread of a new spirituality, coupled with the break-up of traditional forms of life (Taylor, 2007a, pp. 67-69). There was an emphasis on imitating the virtues of saints rather than venerating their bones (Taylor, 2007a, pp. 72 and 76). Early modern clerical elites, in seeking to enforce standards of piety and orthodoxy, 'came to define the phenomenon of belief in a new way that was sharp enough to make declarations of explicit unbelief - atheism - far more prominent than in earlier times' (Warner et al., 2010, p. 16). Reform movements were linked to 'a project of producing purer religion and demanding more widespread lay adherence to high (even monastic) standards of purity. The effort to "cleanse" Christianity of folk beliefs and practices 
was one part of this story. So was the rise of new morality governed by self-discipline but also ever-proliferating rules...' (Warner et al., 2010, p 15).

The discussion that follows will juxtapose Casanova and Taylor's perspectives on secularity and secularization in the West - specifically their arguments about institutional and functional differentiation and the emptying of public space of God; and about belief in God becoming 'one option among others' and the urge to reform with the case of the Muslim Brotherhood. Before proceeding with this comparison, however, I outline in the section immediately below the broader parameters within which it is situated. More specifically, the section explains the rationale behind my focus on the Brotherhood and introduces the movement, setting it within the context of Islamism and of Egyptian politics. I argue that the Brotherhood constitutes a 'hard' case of comparison with the Western experience because, like all Islamist movements, it purportedly fights against secularity; and contrast my approach in this paper, of taking religion and secularity as co-constituted, with approaches which treat them as separate spheres. I finally turn to methodological issues and set out the rationale behind the selection of the primary sources.

\section{'Islam', Islamism and the Egyptian Muslim Brotherhood}

In their works of 1994 and 2007 respectively, Casanova and Taylor focus mainly on the Western world but they make intriguing allusions to the non-West, and specifically to 'Islam' and 'Islamic societies' ${ }^{4}$ Taylor argues that, outside the West, 'almost all other contemporary societies (e.g., Islamic countries, India and Africa)' - and people in the rest of human history - do not live in a secular age (Taylor, 2007a, p. 1). When he discusses secularity in the third sense, of belief being one option among others, he writes that 'Clear contrast cases today would be the majority of Muslim societies, or 
the milieu in which the vast majority of Indians live in' (Taylor, 2007a, p. 3). In his 1994 book, Casanova argues that Islam is 'the unique historical case' which was born both as a religious and political community and that the umma (community of believers) saw itself most of the time as both religious and political community. He qualifies this by adding that it is wrong to say that in Islam religious and political spheres were not differentiated and that institutional separation did exist, even though the foundational myth that religious and political spheres were merged remains important (Casanova, 1994, p. 48). Elsewhere, Casanova argues that 'we need to go against exceptionalisms as much as against invidious misleading contrasts between the secular liberal West and the religious fundamentalist "Rest" (Casanova, 2003, p. 23). These caveats notwithstanding, Casanova shares with Taylor the belief that at the very least 'Islamic societies' have experienced secularity and secularization in very different ways compared to the West.

But are these differences between Western and 'Islamic' settings as stark as Casanova and Taylor contend? Historical experiences are particular and discrete, of course, but are there, perhaps, more commonalities between the West and 'Islam' than Casanova and Taylor suggest? Clearly it would be impossible within the confines of this paper to offer a full answer to these questions. I pursue an answer to them by examining how the processes 'secularity' and 'secularization' have shaped the ideology of the Muslim Brotherhood, a pivotal movement in the history of Islamism in Egypt, the Middle East and the wider Islamic world. The paper does not treat the Brotherhood as representative of 'Islamism' - there is no paradigmatic case of a phenomenon which comprises far too wide an array of often disparate movements - but it takes the Muslim Brotherhood as a significant enough player to offer a basis for some general observations about Islamism. 
The Brotherhood was created by Hassan al-Banna to promote Islam and Islamize Egypt and the Muslim world more generally; it served as a model for the establishment of a number of similar Islamist organizations across the Middle East. In the period of the 1930s and 1940s when Egyptian politics and society were dominated by the monarchy and a landowning class of 'notables', as well as by the British, the Brotherhood gradually emerged as the main 'religious' opposition and, although other religious associations also existed, it quickly established itself as the main organization of this kind. It became an important political player, striving both for domestic reform and for national independence (though of a different kind from the one sought by the dominant Wafd Party which was more secularist in its orientation).

Following the crushing of the old regime after the coup of 1952, the Brotherhood emerged as the main opposition to the new Free Officer government, a fact that confirmed its centrality in Egypt's religious field. As a result, it suffered tremendous repression by Gamal Abdul Nasser in the 1950s and 1960s. It re-emerged in the 1970s as a result of Anwar Sadat's policy shift and grew in appeal, in tandem with many other religious organizations in Egyptian society (Zollner, 2009). The informal gama'at organizations, which flourished predominantly in Egypt's universities, were vital in Egypt's Islamist resurgence and were closely connected to the Brotherhood: as we shall see below, the 1970s university generation shaped the reformist trend of the 1990s and 2000s (al-Anani, 2016). From the 1970s a number of radical Islamist groups, such as Takfir wal Hijra and Islamic Jihad, also emerged in Egypt but the greatest challenge to the Brotherhood was presented in the 1990s by the Gama'a Islamiyah, which opposed its gradualist politics (Dalacoura, 2011, pp. 113116). In terms of status and popularity, however, the Brotherhood continued to be the biggest movement in the Egyptian Islamist field, as evidenced in the group's powerful 
standing in the country's professional organizations and its important role in parliament and politics (even though the Brotherhood was banned, its contested all elections from 1984 onwards putting forward its candidates as independents) (El-Ghobashy, 2005). It was also extremely instrumental in shaping public debate, for example in many of Egypt's 'culture wars' over censorship, blasphemy and the role of religion (often with the collusion of the state and the official religious hierarchy which centred on the ancient institution of al-Azhar).

The culmination of the Brotherhood's rise in popularity and its social, ideological and political success came after a popular uprising and action by the Egyptian army overthrew the regime of Hosni Mubarak in 2011. In the series of electoral contestations which followed, the Brotherhood won a majority of parliamentary seats (with almost half the popular vote in the 2011-2012 national elections) and one of its leaders, Muhammad Morsi, became president of the republic in 2012 (Masoud, 2014, pp. 123-182). Salafi organizations which decided to also enter the political fray and compete for parliamentary seats, won a quarter of the popular vote. Despite its suppression after the July 2013 military coup in Egypt, the movement has remained a major actor in the politics of the country. In the wider Middle East, too, Muslim Brotherhood organizations - originally set up under the inspiration of the Egyptian branch - continue being key players (Pargeter, 2016).

I have selected the Muslim Brotherhood as the focus of my analysis in this paper, not only because of its seminal importance in Egypt's religious scene, and within Islamist politics in the Middle East more broadly, but also because, as a movement committed to the Islamization of society and politics, and therefore battling secularity as a condition and reversing secularization as a process, it constitutes a 'hard' case for the study of these two phenomena in a Muslim-majority setting. The Brotherhood 
advocates a comprehensive Islamic social and political order in Egypt and elsewhere in the Islamic world based on a model which it purveys as an alternative to the existing secular order. This statement may appear simplistic in light of the multiple and often conflicting interpretations about the causes and purpose of political Islam, as well as the very categories of 'religion' and 'politics' which have been used to interpret it (Volpi, 2010). Whatever meaning we ascribe, however, to the objectives of Islamist movements, the Brotherhood at the very least purports to accomplish the total reorganization of society and politics along Islamic lines and wants to offer an Islamic alternative to the secular one in place. Furthermore, the Brotherhood claims to run its internal organization along Islamic lines. Its members join the organization following a rigorous process of religious indoctrination and initiation and fully-fledged membership signifies a commitment to Islamization in their own lives and social circles, as well as of the whole Egyptian society through dawa (preaching). The Brotherhood plays a role in many aspects of an individual member's life (the economy, sport, social relations), even though members are not expected to give up their professions or other social and personal identities to join it (al-Anani, 2016, pp. 65, 120). If, despite these consciously and purposefully 'religious' intentions and policies, the Brotherhood is still defined and shaped in significant aspects of its ideology and orientation by secular realities and conditions, the paper's argument will be all the more convincing.

In an article on the ideational evolution of the Muslim Brotherhood between 1984 and 2012, Sumita Pahwa (2013) shows how the movement has adapted to democratic and secular ideas by reframing them in religious terms. This process of 'secular translation' has resulted in a hybrid, 'secularized' Islamism, according to Pahwa. The Brotherhood's political mission has moved away from applying a 
preconceived religious project to an emphasis on achieving the public good for Muslims. The leadership thus justified participation in a 'secular' political order that past leaders had treated as too corrupt (Pahwa, 2013, pp. 192-193). They developed a more 'secular' proposition about the benefits of sharia (Islamic law) 'from one that emphasized the authority and sovereignty of religion over public life to one that argued that shariah would uphold popular rights and the public good'. Religious law was framed as "valuable in achieving "secular" functional goals like law and order, rather than simply religious duty' (Pahwa, 2013, pp. 194-195). Pahwa suggests that the reason why the Brotherhood's ideology has become 'secularized' is that the Brotherhood has undergone a process of political adaptation.

Pahwa's argument helps me spell out an important point with regards to my own. She offers an alternative explanation to mine for the secularization of the Brotherhood's ideas; my starting point, purpose and conclusion are different from hers in significant ways. Although Pahwa's argument is also about secularity and secularization in so far as they shape the Brotherhood's ideas and ideology, she juxtaposes religion and the secular, seeing them as distinct and even antithetical; whereas I am suggesting that religion, or at least religious revivalism in the form of Islamism, is shaped within the boundaries and structures created by a secular (material) reality. That secular reality defines the Brotherhood's worldview as well as the way it functions and operates. Islamic religious 'revival' is a product (Roy, 2010, p. 2) or a phenomenon (Zubaida, 2005, pp. 445-446), of secularization, not its opposite. ${ }^{5}$

The analysis of the Muslim Brotherhood below is based on a wide-ranging evaluation of the movement through secondary sources but also on primary materials, namely a number of Muslim Brotherhood public statements which, taken together, put forward comprehensively the Brotherhood's proposed alternative Islamic order. They 
are the March 2004 Initiative for Domestic Reform in Egypt (Muslim Brotherhood, 2004); the Brotherhood's platform for the 2005 parliamentary elections (Muslim Brotherhood, 2005); the 2007 programme for the Shura Council elections (Muslim Brotherhood, 2007a); the 2007 Draft Political Platform (Muslim Brotherhood, 2007b); the Muslim Brotherhood Programme for the 2010 parliamentary elections (Muslim Brotherhood, 2010); the political programme of the Freedom and Justice Party (the political wing of the Brotherhood, established in 2011) (Freedom and Justice Party, 2011). I have also consulted the text of the 2012 Egyptian Constitution in whose drafting the Brotherhood was instrumental. In her seminal study on the Brotherhood, Wickham focuses particularly on the 2004 and 2007 documents, which constituted major, detailed statements outlining the Brotherhood's ideas and political positions; I follow her lead in delving in them more extensively than in the other documents (Wickham, 2013, pp. 104-107, pp. 124-126).

The documents were selected because they encapsulate the Brotherhood's vision of an Islamic social and political order in its totality, as an alternative to the secular order. They constituted major 'events' and were the object of extensive public debate in Egypt (particularly the 2007 political party platform). It is through these documents - which represented the movement's involvement in the political fray and engagement with public debates about the future of Egypt - that it is possible to explore the degree to which the movement is shaped by the processes of modernity and state formation. Clearly, there exists a larger body of formal and informal publications, statements, interviews, and other pronouncements by the Brotherhood (Mellor, 2018). However, it would be unfeasible for the purposes of this paper to cover such an enormous body of material which, in any case, most often deals with more particular 
aspects of the proposed social and political order and a variety of other issues (personal, theological) not relevant to the argument.

Given the plurality of views within the Brotherhood and the profound tensions between its various internal ideological strands, it is possible to object that the documents I focus on in the sections below were distributed for public consumption whereas documents internal to the movement, are more representative of their 'true' thinking. However, the charge of dissimulation would be more relevant to the Brotherhood's positions on democracy and pluralism, which is not my subject here. Furthermore, with so many different strands and conflicting views behind the scenes, it is impossible to treat some views as 'truer' or more representative of the Brotherhood than others (Wickham, 2013, p. 186). The Brotherhood's formal public statements, however, even though they emerged through a process of internal contestation and compromise, are indisputable owned by the movement.

The selection of documents for consideration in the paper was also determined in light of the changing internal balances between the Brotherhood's multiple factions. I focus on the public statements of the movement in the 2000s and 2010s and not before for reasons linked with its ideological evolution. ${ }^{6}$ Two internal conflicts run through the Brotherhood in its post-Nasser period. First, between the proponents of dawa who argue that the movement should focus on religious missionary activity, and those who want it to play a more openly political role. Second, between conservatives and reformists whose disagreements centre mainly on the issue of democracy and pluralism. There is considerable consensus among analysts of the Brotherhood that the conservatives gained the upper hand from the late 1990s onwards (Wickham, 2013, pp. 120-153; al-Anani 2016, pp. 146-147) even though, as just mentioned, the internal divisions rumbled on. Even during periods of conservative ascendancy, however, the 
Brotherhood's public documents indicate that secular structures and secularizing processes shape the movement's ideology, which lends weight to my argument.

\section{Institutional and functional differentiation and the emptying of public space of}

\section{God}

Secularity in Taylor's sense of 'relegating God and religion to the margins of the various public spheres' (Taylor, 2007a, p. 425) (secularity 1) appears to be an alien concept in the Middle East in general and Egypt in particular. Politics there is infused with religious imagery and symbolism, which are employed constantly by government and opposition forces. Over and beyond politics, there is an intermeshing of religion with many aspects of public life. Places and spaces of religious worship are numerous and well attended. State, private and social media churn out a constant diet of religious 'advice' and discussion. Religious leaders are figures of authority, enjoy considerable status and are expected to comment publicly on morals, culture, society, law, politics and even foreign policy (Bayat, 2007, pp. 136-186).

The apparent pervasiveness of religion, however, obscures the deeper reality of secularization in the sense of institutional and functional differentiation, in terms similar to those described by Casanova, which has occurred in the Middle East in general and Egypt in particular. In different ways and from discrete disciplinary perspectives, Marshall Hodgson (1977) and Sami Zubaida (2003, 2005), among others, have shown that, with the gradual introduction of the nation-state in the post-nineteenth century Middle East, a new set of extensive, if not all-powerful structures of authority came into being. Their emergence entailed the cutting off of religious authorities from social, educational, cultural and political spheres which they had previously been present in or in some cases even dominated. Religion was not abandoned necessarily 
but became 'compartmentalized' to particular corners of people's lives (Zubaida, 2005, pp. 440, 444). In the most important area of law, secularization occurred because the modern nation-state vested itself with the sovereign right to legislate, further wresting authority away from religious authorities.

Despite the fact that, as pointed out above, in Egypt society and politics is infused with religious ideas, symbols and values, the logics which pervade the different areas of public life are secular. One would have expected the Muslim Brotherhood, which proposes to 'recapture' these areas of public life for Islam, to be suggesting a new, religious logic to be applied to each of them separately. However, as its public statements show, the Brotherhood has not been able to put forward such alternative religious logics and its proposals for an 'Islamization' of politics, the economy and culture remain at surface or rhetorical levels.

The greatest part of the 2004 Initiative for Domestic Reform text focuses on the political, economic and social spheres with scant allusion to religion. The document puts forward very similar demands to those of secular Egyptian opposition movements such as the individual's right to political participation; changes to the electoral system and in education; economic development, the combating of poverty; fighting corruption and eliminating torture; limiting the power of the presidency; and the abolition of emergency rule. It states that the Brotherhood believes in 'the economic system stemming from Islam as a religion and a complete, comprehensive way of life that stresses freedom of economic activity'. However, suggestions such as having the right to earn a living, well-studied (sic) privatization, the liberalization of trade policy, encouraging exports and toughening penalties on corruption, are not particularly 'Islamic'. The document stresses that moral values must permeate the fields of education and scientific research but in fact mostly deals with mundane issues such as 
'increasing scientific missions abroad' and 'improving the conditions of teachers'. The areas of poverty and social relations are treated in a similar manner. It is only the fields of women and culture which contain greater emphasis on moral religious values.

The Muslim Brotherhood National Assembly Elections Platform of 2005 (Muslim Brotherhood, 2005) is similarly taken up, in its greatest part, with outlining the movement's political, economic and social goals in a way which has little to do with Islam. It emphasizes that 'there is no one in Islam who has religious authority - whoever he is - except the authority of good preaching, calling for good and warning of evil'. The vision which the document proclaims is divided into 'three axes': revival (which refers to human rights, freedoms and culture as well as moral values), economic development and reform. From the fifth page until the end of the forty-four-page document (in its English translation), the focus is on these secular areas with the exception of the discussion on moral values and women. There are references to the Prophet Muhammad and to God in these two sections but most of the section on women deals with practical issues such as literacy and small loans. Other parts contain the occasional reference to God and some religious quotes but the bulk of the text deals with material issues.

The Electoral Programme for the Shura Council election of 2007 (Muslim Brotherhood, 2007a) is structured in a similar way. The biggest part of the document again deals with material and mundane matters, as does the Programme for the 2010 parliamentary elections (Muslim Brotherhood, 2010). The 2007 Draft Political Platform (Muslim Brotherhood, 2007b) contains a number of references to Islam, religious authority and religious principles. Attention to education and culture is declared a primary objective because it is through them that Islam will be promoted and safeguarded. Culture must be reformed on the basis of 'Islam's values and principles'. 
The bulk of the 2007 document, however, is also concerned with political, economic and social issues without linkage to religion. Following a brief introduction, it is divided into four parts: principles and directions of the party; the state and the political system; education, development and economic policy; social justice and cultural renaissance. Each part includes separate chapters on distinct areas. The table of contents is a clear visual presentation of the secular nature of the document: with the exception of one religious term (shura) mentioned in the context of the discussion of the political system, and one reference to 'religious affairs' in the context of the discussion of social justice, the section and chapter titles contain no reference to Islam. Page upon page, the document considers technical and pedantic issues in a fashion indistinguishable from the text of any 'secular' political party or movement.

The Freedom and Justice Party Electoral Programme of 2011 (Freedom and Justice Party, 2011), presented to the Egyptian electorate for the Parliamentary elections of that year, was written in a format similar to the public documents of its parent organization. This is evident in the table of contents, which is dominated by the issues of freedoms and political reform (Part 2), social justice (Part 3), integrated development (Part 4) and regional leadership (Part 5).

A common thread running through the public statements of the Brotherhood examined above is the movement's advocacy for a 'civil state with an Islamic reference'. The idea has been discussed extensively by analysts of the Brotherhood (Harnisch \& Mecham, 2009; Wickham, 2013, p. 280; Tadros, 2012) but mostly in the context of assessing the Brotherhood's true intentions on democracy and human rights, which is not my subject. I would suggest that the concept of the 'civil state' - which is implicitly a state devoid of religion, as seen by the addition of 'an Islamic reference' as a separate area - is evidence of the extent to which secular structures have permeated 
the worldview of the Brotherhood. In the Brotherhood's party political platform (Muslim Brotherhood, 2007b, p. 10) we see the reason why: an 'Islamic state' is defined as a 'civil state' in the sense of elected citizen performing jobs 'on the assumption of competence and experience of specialized technical and political roles' - an admission that, in the modern state, institutional and functional differentiation is an inescapable reality.

The above documents contain neither an organic nor an elaborated link between the religious references contained within them and the main body of their programmatic declarations. A good example can be found in the Freedom and Justice Party Electoral Programme (2011) section on Social Justice (pp. 17-21), at the start of which the religious tax obligation for charity (zakat) and of the waqf (religious charitable trusts) are mentioned. They are presented as methods of reducing poverty but, strangely, they are not discussed subsequently and there is no attempt to explain how they would alleviate Egypt's social problems in practice. The same can be observed in all the public statements of the Brotherhood investigated in this paper but it is all the more striking with the FJP programme, given the context of the post-2011 uprising which was infused by demands for social justice.

A possible objection to the argument in this section is that what makes a critical difference - and what is, in fact, proposed by the Brotherhood in its statements - is that activities in the secular public spheres (economic, political, social) are infused with and carried out in a religious spirit. This argument happens also to be made by Charles Taylor who distinguishes between secularization in the sense of institutional or functional differentiation, and secularity (1), the emptying of public spaces of God, in the following way: 
the fact that activity in a given sphere follows its own inherent rationality and doesn't permit of the older kind of faith-based norming doesn't mean that it cannot still be very much shaped by faith. Thus, an entrepreneur in a modern economy couldn't accommodate the mediaeval Church interdict on usury, but that wouldn't prevent a devout Calvinist from carrying on his business to the glory of God, giving much of the proceeds to charity, etc. Similarly, a modern doctor will not usually send her patient to touch a relic, but her vocation to medicine may be deeply grounded in her faith (Taylor, 2007a, pp. 425-426).

In the passage, Taylor misses an important aspect of secularization theory which is crucial to my argument about the Brotherhood. It may indeed be the case that the doctor will see her faith as informing how she conducts her profession, and she may be ready to proclaim the strength of her belief from the rooftops while doing so. However, the doctor still has to operate within the rules of medical science when treating a patient: if she attempts to treat the patient by using relics she will lose her license. Furthermore, this is the case, not just in the West, but also according to the law (irrespective of whether it is properly applied or not) in all Middle Eastern states. In the Middle East, differentiation in the Weberian sense has occurred and this has caused more of an emptying of the public sphere of God (Taylor's secularity 1) than meets the eye: an appeal to God and the insignia of religion may prevail everywhere but religious logics do not pervade public spheres, despite persistent claims to the contrary.

\section{Belief in God as 'one option among others' and the urge to reform}

Egypt today, where (admitting to) religious unbelief - for the country's Coptic minority as well as the Muslim majority - is almost beyond the pale (Schielke, 2012), appears to confirm Taylor's argument that in Muslim societies religious belief has not become one option (secularity 3), in the same way it has in Christian or post-Christian ones (Taylor, 2007a, p. 3). However, here again appearances are deceptive. It is, indeed, the case that 
belief, not unbelief, is the 'default' position in Egypt and that belief has not 'fallen off' as it has in the West (Taylor's secularity 2). However, belief has become one option among others in Egypt (secularity 3), albeit in a very specific manner: as the conscious adoption of intensive religiosity and becoming a set of identifiable objectives, to be deliberately pursued by the faithful individual.

As noted above, levels of religiosity in Egypt - from which the Brotherhood has benefited and to which, in turn, it has contributed - increased after the 1970s (Abdo, 2000); which indicates that great numbers of Egyptians opted to become more religious. The contrast between the secular atmosphere of the 1950s and 1960s and the subsequent emergence of a public sphere infused with Islamic symbolism is vividly described by many observers of the Egyptian scene (Al Yafai, 2012). In the 1960s, society and politics were dominated by 'secular conceptions, including Arab nationalism, Arab socialism and Marxism'; it was in the decade after the Arab defeat of 1967 that 'political Islam emerged as an important force' (Flores, 1988, p. 27).

The characteristics of religious revivalism in Egypt have similarities with the phenomena described by Taylor as having happened in Europe (which were outlined in some detail in the first section of the paper): the intensification of religious faith in Egypt after the 1970s also occurred within the context of secularization. It entailed an emphasis on prayer, dress, ritual practice and the textually correct understanding of ritual; and the rendering of atheism/unbelief as something that could be 'identified' or 'declared' (and, as a corollary, combatted). It also involved the widespread belief that Egypt's laws should be in accordance with Islamic values and principles (Schielke, 2012, p. 303, and note 13, p. 318). Faith is consciously (re)adopted and leads to the active pursuit of religious obligations in a purposeful and considered manner. It is the result of a personal, an individual decision. 
The Muslim Brotherhood was part and parcel of the wider religious revivalism in Egypt. Its establishment in the 1920s can be seen as linked to the secularization process - discussed in the previous section - which transformed Egyptian state and society from the early nineteenth century (Mitchell, 1991). The role of the individual is central in the movement's philosophy and world-view. From the start, the Brotherhood adopted a 'bottom up' strategy: Islamization would begin with the individual, spread upwards to society and eventually transform the state (Mitchell, 1993, p. 234; al-Anani, 2016). Similarly to other Islamist groups in Egypt and the Middle East, the movement saw its ranks swell by members joining as a result of individual choice (even though joining may have been underpinned by a yearning for belonging to a group). The movement has been, typically, stronger in dynamic urban environments (Kupferschmidt, 1982; Mitchell, 1993, p. 329) where social bonds and communities are in flux. Brotherhood members have been, frequently, 'born-again' Muslims, often distancing themselves from the older generation and/or their families.

Reforming Islam, according to the Brotherhood, involved ridding it of superstition and the false accretions in belief and ritual accumulated over time and restoring a pure and correct understanding of the faith. The Brotherhood's birth had been closely linked to the wider intellectual movement of Salafism in the Middle East of the late nineteenth and early twentieth centuries. Salafism constituted an attempt to engage with modernity and the ideas of the Enlightenment and preached the return to the origins of Islam by eliminating the popular ideas and practices which were said to have distorted the faith over the centuries and undermined its purity and rationality. This idea continues being at the core of the Brotherhood's purpose and message.

For the Brotherhood, reforming Islam involved the application of high standards to the faith. The implicit assumption here is that these standards exist 'outside' or 
independently of the believer, and that they can be identified by him or her. They can then be 'implemented' at either the personal or the collective level. Society is to be reformed along the lines of 'Islam' and thereby attain the ideal that it (Islam) purportedly proposes. One thing that the Brotherhood's slogan 'Islam is the solution' signifies is that Islam contains standards or guidelines which can be enforced and thereby improve society and solve its problems.

The Brotherhood's call for the application of the sharia can similarly be seen as part of the aim or process of reform, involving the identification and implementation of the correct standards or criteria of the faith. In the Muslim Brotherhood's ideational framework, sharia is presented as the guide or blueprint for the ideal society. This is a modern understanding of law as code, quite alien to how sharia had been conceived of and functioned in Islamic settings in the pre-modern period. If sharia can be codified it can also be controlled by political authority. Zubaida outlines how this transformation came about with the 'etatization' of law in the Middle East from the nineteenth century onwards. For example, whereas sharia had treated litigation as a claim of one private party against another, with the creation of the post of prosecutor general, who assumes a public function on behalf of the state, the implicit concept of 'the public interest' is introduced (Zubaida, 2005, p. 131). Wael Hallaq describes a similar process of transformation of sharia with the emergence of the state in the modern period (Hallaq, 2009). For Joseph Schacht, 'Whereas a traditional Muslim ruler must, by definition, remain the servant of the sacred Law of Islam, a modern government, and particularly a parliament, with the modern idea of sovereignty behind it, can constitute itself its master' (Schacht, 1964, p. 101). Modernist legislation 'does not merely restrict the field in which the sacred Law is applied in practice but interferes with the traditional form of this law itself' (Schacht, 1964, p. 3). The Brotherhood's call for the laws of Egypt to 
be reformed along the lines of the sharia, and its implicit claim that it can achieve this reform if it takes over the reins of government, indicate that the Brotherhood has accepted and internalized the modern conception of state and law.

The public statements issued by the Brotherhood in the 2000s and 2010s illustrate, in tangible ways, how the movement approaches the role of the individual and the issue of reform. They demonstrate that it sees faith as one 'option', to be actively pursued and encouraged on the basis of sharia as blueprint.

The 2004 Reform Initiative states the importance of applying Islamic values and rules to Egypt. It asserts that the first step towards realizing the Brotherhood's vision is 'building the Egyptian individual' by ensuring that faith and righteousness are encouraged and protected both in the private and public spheres. It sees the mission of the Muslim Brotherhood as 'building the Muslim individual, Muslim family, Muslim government and the Muslim state that leads Islamic countries, gather all Muslims, regain Islamic glory'. It calls for comprehensive reform (islah) in conformity with the sharia. The document argues that 'political stagnation, corruption and social injustice, in addition to scientific and technological backwardness' threaten 'Egypt's national security, its national standing, Islamic pioneering role and its international role'. These problems will be overcome through reform which is, in turn, to be achieved through legal and constitutional channels, by applying sharia.

The 2005 National Assembly Elections Platform describes 'the Islamic method' as linking 'the constituents of reform', moral values and reforming humans; which in turn would lead to a fall in the rates of corruption. More than a third of the document deals with political, economic and social reform. The 2007 Electoral Programme for the Shura Council election (Muslim Brotherhood, 2007a), also starts with the proclamation of the Brotherhood's 'reform approach' 
and asserts the slogan 'Islam is the solution'. The Brotherhood promises to work to 'amend laws and make them accordant to the Islamic Sharia as being the main source of legislation' (Muslim Brotherhood, 2007a, p. 15). Although the document argues that Islam rejects a theocratic state in favour of a civil one, as we saw, it also states that the movement has [sic] 'sharia that constitutes a system for construction, progress, rise and reform' (Muslim Brotherhood, 2007a, p. 2). The emphasis here, along the lines of the movement's religious mission and orientation, is to rejuvenate and rebuild 'the Egyptian personality' on the basis of ethics and faith: the parallels between the individual believer and the individual citizen, from whose internal individual transformation would stem social and political transformations, are unmistakable. The Programme for the 2010 parliamentary elections (Muslim Brotherhood, 2010) draws on the Koran to mention the issue of reform (islah), with a direct quote from Hud: 88 attributed to the prophet Shu'aib: 'I only intend reform as much as I am able. And my success is not but through Allah. Upon him I have relied, and to Him I return'. The document re-asserts that the comprehensive 'logo' of the Brotherhood is 'Islam is the solution'.

The 2007 Draft Political Platform (Muslim Brotherhood, 2007b), treats 'Islam' as a set of precepts or prescriptions to be realized through activism. The word 'reform' is reiterated in the ninety-five-page-long document (in its English translation) approximately forty times and it pertains to all areas of life, political, social, economic and cultural. The first chapter of the first part begins by stating that 'the principles of Islamic sharia [are] the main source of legislation' and that 'political and constitutional reform is the starting point in [rest] all spheres of life' (Muslim Brotherhood, 2007b, p. 5). Sharia is seen as a solution for all social ills (see for example p. 70 where it is argued 
that when sharia was implemented in past societies, they were the most stable, secure and tranquil and the crime rate was reduced). Individuals can be 'persuaded', using a variety of policies or other means such as dawa, to adopt Islam; this implies that it has become one possible avenue among others, to be pursued as a matter of choice. Those individuals are then ready to, collectively, move into the ideal society. This will be created, presumably under the vanguard of the Brotherhood, by implementing the blueprint provided by the sharia.

The Justice and Freedom Party Electoral Programme of 2011 (Freedom and Justice Party, 2011) inevitably focuses less on religion than the documents of its parent organization but it is infused by a similar spirit and contains similar approaches and goals with regards to the individual and the idea of reform. It reiterates ideas about the individual Egyptian citizen and the importance of enriching his or her personality 'spiritually, intellectually, scientifically, and physically' with a view to achieve 'a leap in the development of the nation and the homeland'. The individual personality is the source of collective change (Freedom and Justice Party, 2011, pp. 23-26). The centrality of sharia is also reasserted. A careful reading of the quote below reveals how sharia's role is indistinguishable from modern law's in that it regulates aspects of individual and public life:

The state envisaged in our program is the national constitutional Islamic modern democracy, based on Sharia (Islamic law) as a frame of reference. By its nature, Sharia nurtures aspects of faith, worship and morality, and also regulates various aspects of life for Muslims and their non-Muslim partners on the homeland. However, in some (few) cases, Sharia regulates these aspects through definitive texts with direct relevance and significance (Freedom and Justice Party, 2011, pp. 10-11).

Some of these objectives were carried through to Egypt's 2012 constitution (Egyptian Constitution, 2012), which was written by an Islamist majority (the Brotherhood/FJP 
and the Salafi parties combined dominated the Constituent Assembly). Article 2, which makes the principles of sharia the principal source of legislation, had been the same in the previous constitution of 1971. However, the Islamists added a controversial article (219) which elaborated on what these principles meant: 'The principles of Islamic Sharia include general evidence, foundational rules, rules of jurisprudence, and credible sources accepted in Sunni doctrines and by the larger community' (Egyptian Constitution, 2012). Once again, this statement reveals the Brotherhood's understanding of sharia as the blueprint for the ideal society: an understanding which, as pointed out above, is alien to sharia's original function and spirit as it had emerged in the pre-modern period.

\section{Conclusion}

The appeal of the Muslim Brotherhood undoubtedly attests to the prevalence of religious belief in Egypt. The Brotherhood, in turn, actively seeks to promote and spread religious belief and claims that membership in the organization entails the permeation of all aspects of the individual's life by Islam. However, on a more complex and multi-dimensional understanding of secularity and secularization, the Muslim Brotherhood can be seen as a partly secular and secularized (if anti-secularist) entity.

This is for two reasons. First, as illustrated by the history and ideas of the movement, and more specifically the public statements examined in this paper, the Brotherhood's Islamist vision is shaped by secularization as institutional and functional differentiation. These documents, which present one important agreed position within the Brotherhood on the ideal society and politics, overwhelmingly concentrate on social, economic and political areas which are defined by the emergence of the modern nation-state and its derived structures. The Egyptian state, similarly to others in the 
Middle East, has appropriated since the nineteenth century a variety of functions educational, legal, cultural - from religious authorities. Islamist movements are firmly embedded within Middle Eastern societies and have therefore also been molded by such processes of secularization. The Brotherhood's conception of politics does not - cannot - challenge this long-established fact but takes the basic elements of the Egyptian state structures as a given. Its 'moral' propositions in social areas such as the arts, culture, education and the family are influenced by Islamic principles. The great majority of proposals in the documents, however, pertain to areas of public life (the economy, politics) which have nothing to do with religion. Behind the religious symbolism and imagery which pervade Egyptian public life and the Brotherhood's own discourse, secular logics prevail.

The above argument has broader significance for the viability, appeal and prospects of Islamism as a movement and an ideology. The Brotherhood's inability to offer distinct Islamic programmes or ideas in the spheres of the economy and politics, which continue being dominated by non-religious, internal logics and remain autonomous of religion (Casanova, 1994, p. 20), renders the Islamist project unrealizable; it also explains the group's excessive concentration on a 'moral' agenda. Olivier Roy has described this as 'the failure' of political Islam (Roy, 1994) and argued that it 'comes from the fact that it tried to compete with secularization on its own ground: the political sphere (nation, state, citizen, constitution, legal system). Attempts to politicize religion in this way always end up secularizing it, because it becomes mixed up with day-to-day politics...' In this sense, secularization 'has worked' (Roy, 2010, p. 2). Bruce Lawrence, positing that the nation-state system is 'the inescapable political norm for all humankind', argues that fundamentalists 'must perform on a stage that they did not construct and which they cannot destroy' (Lawrence, 1989, p. 227). 
The second reason for describing the Brotherhood as a phenomenon of a secular age is that it treats 'Islam' as a set of beliefs to be put into practice by the believer who, in turn, opts to adhere to the faith on an individual basis. Reform is pursued along the lines of these beliefs, which are identifiable and treated as separate from the believer; they are used as criteria to 'improve standards'. The paper illustrated this point with reference, again, to the history and ideas of the movement and more specifically the extensive concentration of its various public documents on the subject of reform. The Islamist project outlined in these documents, encapsulated in the slogan 'Islam is the solution' and the proclaimed goal of sharia, is conceived of as a blueprint for the ideal society and is to be actively implemented by the movement and its followers (the irony being that the tangible prescriptions for this ideal society have nothing much to do with religion, as we saw).

One implication of the above analysis is that there exist more commonalities, when it comes to secularity and secularization, between Western and Muslim-majority societies than Casanova and Taylor presume. This is not an assertion that they follow similar trajectories but that the stories have interesting parallels, stemming from these societies partaking in modernity's broader, worldwide trends. The conceptualization of religion as separate and distinct from the believer (the 'subject') and its 'objectification', which are implicit in the Brotherhood's approach and in Taylor's description of the idea of reform, have also been globalized (Mahmood, 2010, p. 283).

Referring to the West, Taylor argues that it is impossible to define the idea of 'secularization' in a precise or agreed on manner and numerous questions can be asked about its precise meaning (Taylor, 2007a, p. 427). As already pointed out at the start of this analysis, there cannot be a universal agreed-upon definition of 'secularization' and 'secularity' and it is more helpful to think along the lines of 'multiple secularities' than 
one secular experience. Within the context of Western or European history as well, paths are varied. However, as Taylor claims, despite these uncertainties and caveats, most of us agree that 'something that deserves this title [secularization] has taken place in our civilization' (Taylor, 2007a, p. 426).

This paper did not use the West experience as a measure to evaluate how secularization and secularity have shaped the Muslim Brotherhood, which would have been an exercise in crude Eurocentrism. Instead, the paper argued that the ideas of the Muslim Brotherhood in Egypt, and Islamism more generally, are shaped by a historical experience of secularity and secularization which, although not identical to the Western one, has at least considerable commonalities with it. The wider implication of the paper's argument may be that, even in the thorny area of religion, modernity unifies human experience and the human condition to a greater extent than initially meets the eye.

\section{Notes}

\footnotetext{
${ }^{1}$ My paper is not an enquiry about secularism as a political and ideological project. A connection between secularity, secularization and secularism is suggested by Talal Asad, who questions the liberal assumption that secularism protects civil freedoms from religious tyranny and argues that secularism, far from underpinning state neutrality and rational ethics, is in fact associated with the hegemonic project of the modern state (Asad, 2003, pp. 227-228, 255; see also Mahmood, 2006; Agrama, 2010; Scott, 2014; Hurd, 2007). In my judgement, it is not necessary for the purposes of my argument to engage with this critique.

${ }^{2}$ Casanova and Taylor have addressed Islam with other issues in mind in other writings. Casanova (2001), deals with Islam and democracy; Casanova (2012), is about the treatment of Muslim minorities in Europe and the United States; Casanova (2009), compares gender equality in Catholicism and Islam. Casanova (2003), discusses the Muslim world from a global perspective on secularization, albeit briefly. Taylor (2007b), is about Islam, tolerance and the clash of civilizations. I do not deal with these issues and therefore do not engage with these works.

${ }^{3}$ Taylor explains 'how conditions of secularity have come to shape both contemporary belief and "unbelief" alike'; the religious and the secular are not opposites but are co-constituted (Taylor, 2007a, p. 25; Warner et al., 2010, pp. 5, 8-9).

${ }^{4}$ I place 'Islam' and 'Islamic societies' in quotation marks because I find generalizing about them problematic.

${ }^{5}$ See also note 3 , above.

${ }^{6}$ The Brotherhood's Charter, originally circulated in the 1930s and revised in the 1940s and 1990s, dealt with the movement's internal organization, not its ideology (Mitchell, 1993, p. 163; Wickham, 2013, pp. 127, 130). On the documents of the 1980s see Hamid (2014, pp. 71-77). On the documents of the 1990s see Hamid (2014, pp. 94-96), Wickham (2013, pp. 69-70) and El-Ghobashy (2005, p. 383).
} 


\section{References}

Abdo, G. (2000). No God but God: Egypt and the triumph of Islam. Oxford: Oxford University Press.

Agrama, H. A. (2010). Secularism, society and indeterminacy: Is Egypt a secular or religious state? Comparative Studies in Society and History, 52(3), 495-523.

al-Anani, K. (2016). Inside the Muslim Brotherhood: Religion, identity, and politics. New York, NY: Oxford University Press.

Al Yafai, F. (2012, November 3). The death of Arab secularism. The National. Retrieved from http://www.thenational.ae/arts-culture/the-death-of-arab-secularism

Asad, T. (2003). Formations of the secular: Christianity, Islam, modernity. Stanford, CA: Stanford University Press.

Bayat, A. (2007). Making Islam democratic: Social movements and the post-Islamist turn. Stanford, CA: Stanford University Press.

Burchardt, M., Wohlrab-Sahr, M. \& Middell, M. (2015). Multiple secularities beyond the West: An introduction. In M. Burchardt, M. Wohlrab-Sahr \& M. Middell (Eds.), Multiple secularities beyond the West (pp. 1-19). Boston, MA, Berlin, Munich: Walter de Gruyter.

Casanova, J. (1994). Public religions in the modern world. Chicago, IL: Chicago University Press.

Casanova, J. (2001). Civil society and religion: Retrospective reflections on Catholicism and prospective reflections on Islam. Social Research, 68(4), 1041-1080.

Casanova, J. (2003). Beyond European and American exceptionalisms: Towards a global perspective. In G. Davie, P. Heelas \& L. Woodhead (Eds.), Predicting religion (pp. 17-29). Aldershot: Ashgate.

Casanova, J. (2009). Nativism and the politics of gender in Catholicism and Islam. In H. Herzog \& A. Braude (Eds), Gendering religion and politics: Untangling modernities (pp. 21-51). New York, NY: Palgrave Macmillan.

Casanova, J. (2011). The secular, secularizations, secularisms. In C. Calhoun, M. Jurgensmeyer \& J. VanAntwerpen (Eds.), Rethinking secularism (pp. 54-75). Oxford, NY: Oxford University Press.

Casanova , J. (2012). The politics of nativism: Islam in Europe, Catholicism in the United States. Philosophy and Social Criticism, 38 (4-5), 485-495.

Dalacoura, K. (2011). Islamist terrorism and democracy in the Middle East. New York, NY: Cambridge University Press.

Egyptian Constitution. (2012). 
El-Ghobashy, M. (2005). The metamorphosis of the Egyptian Muslim Brothers. International Journal of Middle East Studies, 37(3), 373-395.

Flores, A. (1988). Egypt: A new secularism? Middle East Report, 153, 27-30.

Freedom and Justice Party. (2011). Electoral programme. Retrieved from http://www.fjponline.com/articles.php?pid=80 [Muslim Brotherhood sites no longer available].

Gorski , P. \& Altınordu, A. (2008). After secularization? Annual Review of Sociology, 32, 55-85.

Hallaq, W. (2009). An introduction to Islamic law. Cambridge: Cambridge University Press.

Hamid, S. (2014). Temptations of power Islamists and illiberal democracy in a New Middle East. New York, NY: Oxford University Press.

Harnisch C. \& Mecham Q. (2009). Democratic ideology in Islamist opposition? The Muslim Brotherhood's 'civil state'. Middle Eastern Studies, 45(2), 189-205.

Hodgson, M. (1977). The venture of Islam, Volume 3. Chicago, IL: University of Chicago Press.

Hurd, E. S. (2007). The politics of secularism in international relations. Princeton, NJ: Princeton University Press.

Kupferschmidt, U. M. (1982). The Muslim Brothers and the Egyptian village. Asian and Africa Studies, 16, 157-170.

Lawrence, B. B. (1989). Defenders of God: The fundamentalist revolt against the Modern Age. San Francisco, CA: Harper and Row.

Mahmood, S. (2010). Can secularism be other-wise? In M. Warner, J. VanAntwerpen \& C. Calhoun (Eds.), Varieties of secularism in a secular age (pp. 282-300). Cambridge, MA: Harvard University Press.

Mahmood, S. (2006). Secularism, hermeneutics, and empire: The politics of Islamic reformation. Public Culture, 18(2), 323-47.

Masoud, T. (2014). Counting Islam: Religion, class, and elections in Egypt. New York, NY: Cambridge University Press.

Mellor, N. (2018). Voice of the Muslim Brotherhood. Abingdon: Routledge.

Mitchell, T. (1991). Colonizing Egypt. Berkeley, CA: University of California Press.

Mitchell, R.P. (1993). The society of the Muslim Brothers. New York, NY: Oxford University Press. 
Muslim Brotherhood. (2004). Initiative for domestic reform in Egypt [unofficial translation by Amany Salem]. Retrieved from http://www.ikhwanonline.com/Article.asp?ArtID=5172\&SecID=356

Muslim Brotherhood. (2005). National Assembly elections platform. Retrieved from http://www.ikhwanonline.com/Article.asp?ArtID=5172\&SecID=356

Muslim Brotherhood. (2007a). The electoral programme of the Muslim Brotherhood for Shura Council. Retrieved from http://www.ikhwanweb.com/article.php?id=822

Muslim Brotherhood. (2007b). Draft political platform. Retrieved from http://www.ikhwanweb.com/article.php?id=15492

Muslim Brotherhood. (2010). Programme for the 2010 parliamentary elections. Retrieved from https://kurzman.unc.edu/files/2011/06/EGY-2010-Al-Ikhwan-alMuslimun-Muslim-Brotherhood.pdf

Pahwa, S. (2013). Secularizing Islamism and Islamizing democracy: The political and ideational evolution of the Egyptian Muslim Brothers 1984-2012. Mediterranean Politics, 18(2), 189-206.

Pargeter, A. (2016). Return to the shadows: The Muslim Brotherhood and An-Nahda since the Arab Spring. London: Saqi Books.

Roy, O. (1994). The failure of political Islam. London: I.B. Tauris.

Roy, O. (2010). Holy ignorance: When religion and culture part ways. New York, NY: Columbia University Press.

Schacht, J. (1964). An introduction to Islamic law. Oxford: Clarendon Press.

Schielke, S. (2012). Being a nonbeliever in a time of Islamic revival: Trajectories of doubt and certainty in contemporary Egypt. International Journal of Middle East Studies, 44(2), 301-320.

Scott, R. M. (2014). Managing religion and renegotiating the secular: The Muslim Brotherhood and defining the religious sphere. Politics and Religion, 7, 51-78.

Starrett, G. (2010). The varieties of secular experience. Comparative Studies in Society and History, 52(3), 626-651.

Tadros, M. (2012). The Muslim Brotherhood in contemporary Egypt: Democracy redefined or confined? London and New York, NY: Routledge.

Taylor, C. (2007a). A secular age. Cambridge MA: Belknap Press of Harvard University Press.

Taylor, C. (2007b, September 17). The collapse of tolerance. The Guardian.

Retrieved from

http://www.theguardian.com/commentisfree/2007/sep/17/thecollapseoftolerance 
Volpi, F. (2010). Political Islam observed. London: Hurst.

Warner, M., VanAntwerpen, J. \& Calhoun, C. (2010). Editor's introduction. In M. Warner, J. VanAntwerpen \& C. Calhoun (Eds.), Varieties of secularism in a secular age (pp. 1-32). Cambridge, MA: Harvard University Press.

Wickham, C. R. (2013). The Muslim Brotherhood: Evolution of an Islamist Movement. Princeton, NJ: Princeton University Press.

Zollner, B. H. E. (2009). The Muslim Brotherhood: Hasan al-Hudaybi and ideology. Abingdon: Routledge.

Zubaida, S. (2003). Law and power in the Islamic world. London: I.B. Tauris.

Zubaida, S. (2005). Islam and secularization. Asian Journal of Social Science, 33(3), 438-448.

\section{Acknowledgments}

I am grateful to the editors and anonymous referees of Economy and Society for the constructive process of evaluation of the paper; and to my research assistant, Buğra Süsler, for being meticulous and forthcoming. The list of others to whom I am grateful would be too long to include here. All errors are mine. 